\title{
Intolerable 3
}

\author{
Donald Middlebrooks
}

HWonald IHthidd éfrooks

The isolafion, INof geffing mail from fiome, nof geffing visifs, inner emptiness and rasing memories "ffus place is slowly becoining off thaf II know:" wanfing fo grieve witien some family member dies buf nof being abel fo do so. recycled days" one day like fle one before if". Wafching freiplessly as prisons become insfifofions of profiff" ffice mosf recenf $y$-pay. having sizures and guards laughing and mafing furt of you during sizures insfead of geffing inedical assisfance, fhe unif confroll cuffung off or just nof responding fo my emeraency call figliff. commissary prices finef freep geffing fingh while pisoner pay stays the same. People who lie fo me a lier is worse fram any offer fype of person they; cantbe frust, have no Frounor, Frave 170 self respect, and are fakes. G. I joe guard's who come in here acting lite boad asses and causing problems. The lack of honor and respect amenast finose of our incarceirated communify. Fafes whio fry fo be what they are nof. Gossipers who fers fales and feep shif sfited up. Being in hare, 